\title{
TELEMATICS SYSTEMS IN ROAD TRANSPORT
}

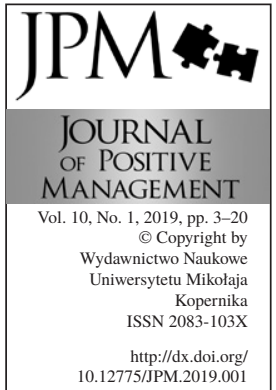

e-mail: w.zalewski@umk.pl

\begin{abstract}
Purpose: The research objective of the article is to assess the level and degree of the use of telematics systems supporting supply chain management based on GPS/GSM/GPRS technology in road transport companies operating in Poland.

Methodology: The research methodology was based on the analysis of domestic and foreign subject literature as well as on surveys carried out in road transport companies in Poland for the needs of a National Science Centre grant.

Findings: The results of the research performed have shown that despite the large popularity and use of telematics systems, the scope of their use is still very low. The tests carried out on a sample of 500 road transport companies operating in Poland allow for applying the outcome of the research done to the general population.
\end{abstract}

Keywords: telematics, supply chain, independence test

Paper type: Research paper

\section{Introduction}

Continuous technological development related to digital techniques, covering more and more areas of life, provides entrepreneurs with a wide range of possibilities to apply solutions in the field of IT, telecommunications and mechanics. By combining advanced technological knowledge and various scientific fields, we are witnessing the emergence of new, specialized areas of application for IT and telematics systems (Bujak et al., 2014). The companies' striving to maximize profits and minimize costs and losses made, look for both technological and organizational solutions that would enable them to achieve their goals efficiently (Riha and Tichy, 2015; Walker and Manson, 2014). Telematics systems have become a widely used tool that allows monitoring, coordinating and optimizing the work of motor vehicles with particular emphasis on the work of trucks and vans. Telematics and technologies (see Mikulski, 2007) of data processing are playing an increasingly important role in transport control and management 
TELEMATICS SYSTEMS IN ROAD TRANSPORT

Wojciech Zalewski systems. These applications are of particular importance for the smooth operation of transport in supply chains, which can directly determine the competitive advantages of companies. Despite the wide availability of these solutions, their level of application and use is very diverse.

The research objective of the study is to assess the level and degree of the use of telematics systems supporting the management of supply chains based on GPS/ GSM/GPRS technology by road transport companies in Poland.

The following research hypothesis was formulated: the low level of the use of telematics solutions by road transport companies in Poland reduces the efficiency of integrated supply chains, since it reduces the quality of services.

The research methodology was based on the analysis of domestic and foreign subject literature as well as on the surveys carried out in road transport companies in Poland for the needs of a National Science Centre grant [1].

The theoretical part of the article explains the concepts related to telematics in particular in relation to road transport, and reviews the latest literature on the subject. The empirical part provides the results of questionnaire surveys carried out within the aforementioned grant.

\section{Telematics in road transport}

The term 'telematics' was introduced by the International Consultative Committee on Telephony and Telegraphy (CCITT) [2], which is part of the International Telecommunications Union. It can be assumed that telematics means telecommunications, IT and information solutions, as well as automatic control solutions adapted to the needs of supported physical systems and integrated with IT systems (Wydro, 2005).

Szymonik (2010) indicates that telematics is 'a transport knowledge department, integrating IT and telecommunications in applications for the management and traffic control needs in transport systems, stimulating technical and organizational activities enabling the efficiency and safety of operation of these systems to be increased. Individual telematics solutions often work together under the control of a superior factor.' Mikulski and Nowak (2010) recognize that telematics is based not only on IT and telecommunications, but also on automation and processing of control signals.

Considering various cases of telematics application, we can distinguish the following ones:

- application to structural solutions, when electronic communication, electronic acquisition and information processing are elements of the system, adequately for the needs of this system;

- used in relation to multiple technical solutions that use IT and telecommunications systems in an integrative way. 
Telematics is increasingly an element of complex integrated systems in terms of defined tasks for transport. In such a system they constitute collections or subsets of basic systems that provide complementary services necessary for users' needs. Nowacki (2006) classifies and groups tasks of telematics systems in such areas of activity as monitoring infrastructure on the road, traffic management and control, broadcasting services for travellers and road users, fleet and cargo management, electronic toll collection systems, accident and rescue services, onboard systems in vehicles.

Telematics creates for road transport the possibility of using technology and methods of remote access to vehicles or loads via a wireless telecommunications network. As one of the executive tools of logistics, it serves not only to support management processes, but also to increase efficiency and competitiveness on the transport market. It contributes to improving transport safety, supporting traffic control, creating and developing databases in enterprises organizations or institutions (Farmer et al., 2010; Yan et al. 2016; Wahlstrom et al., 2014). Due to the use of telematics elements (ICT networks, traffic control systems, electronic vehicle and cargo location systems, electronic document exchange), one can optimize routes (Cattaruzza et al., 2017), which significantly contributes to shortening the time of transporting loads (Schuessler and Axhausen, 2009). Telematics technologies used to track vehicles and loads are of particular importance in the transport of dangerous and high-risk materials (Minni, 2013).

The development of telematics systems and the dissemination of their use in transport contributes to increasing the mobility of freight transport, enriching the service offer of carriers, increasing their competitiveness, applying intermodal solutions in transport and thus to economic activation of regions (Harris et al., 2015). The use of telematics solutions using GPS/GSM devices and GPRS data transmission protocols in road transport allows obtaining a lot of information that is extremely useful in transport. In particular, they enable transport companies to:

- plan routes and optimize the selection of stopping and refuelling places using accurate digital maps;

- analyse and control routes of vehicles or loads, including minimization of their length and costs of carrying the carriage, elimination of abuse, and dynamic handling of transport orders;

- register the basic operational parameters of the vehicle, i.e. its speed, distance covered and route, engine speed, fuel consumption, axle loads of the entire vehicle combination and monitoring of the cargo area, control of on-board systems, temperature in compartments, etc.;

- control the driver's work in terms of compliance with the regulations specifying maximum driving periods, minimum breaks and rest periods, the use of optimal driving techniques to ensure the economic operation

TELEMATICS SYSTEMS IN ROAD TRANSPORT

Wojciech Zalewski 
TELEMATICS

SYSTEMS IN ROAD

TRANSPORT

Wojciech Zalewski of the vehicle - the correct selection of routes, new parking places or refuelling, etc. (see Filipowicz, 2005; Filipowicz and Hober, 2007);

- increase safety in transport, i.e. both road safety as well as the safety of drivers, vehicles and loads;

- lower the threat of terrorism by creating the possibility of permanent control of the cargo space, in particular the inviolability of closing this space and monitoring interference in this space, counteracting illegal migration of people or the threat of terrorism;

- control precise timing of deliveries and implementation of accurate goods distribution.

Each of the currently available telematics systems, if fully utilized, can bring measurable economic benefits, in several aspects. The first one concerns the vehicle's movement on the road, controlled thanks to on-board navigation systems, i.e. route optimization and minimization of travel time, fuel consumption, purchase costs, road toll, etc. The second aspect results from the possibility of continuous supervision of the driver who becomes the sole disposer of the property of great value, which consists of a vehicle or a combination of vehicles and cargo. The third aspect includes checking the correctness of calculating tolls, registered automatically thanks to the use of on-board equipment available in the vehicle. The fourth aspect of the advantages discussed is the possibility of more effective use of human and equipment resources of the company (Lacny, 2010, p. 311). Eventually, they also provide the ability to control arriving at the destination in planned time slots for loading or unloading, which is the basis for assessing the quality of transport tasks in the supply chain.

Supply chain management includes sources of raw materials and suppliers, purchasing policy and gathering of raw materials, flow of materials within the company as well as storage of finished products, distribution, storage and transport. Transport, including road transport, is one of the key processes in the supply chain, which is subject to continuous or random quality evaluation due to the increase in the requirements of recipients in terms of service delivery time, flexibility, availability, and reliability. For this reason, it is important to provide data via telematics to the recipient on an ongoing basis, which is often carried out automatically without the participation of the operator (driver).

The task of telematics is to support, supervise, control and manage transport processes as well as to link these systems as part of all transport tasks implemented in the supply chain. The priority element for the implementation of these tasks in telematics systems are the functions of handling information, which primarily relate to the acquisition and distribution of data relevant to making appropriate management decisions.

When analysing the content of publications related to the issues of transport telematics, especially in the field of road transport, it should be pointed out 
that mainly issues related to technical, organizational aspects, security matters, or describing particular applications of telematics systems are discussed. In both domestic and foreign subject literature there are no studies on the level of application of telematics solutions by road transport companies in the area of supply chains. The exception seems to be the study by M. Kiba-Janiak and P. Tronin (2017), in which the impact of selected telematics systems on the improvement of transport tasks was assessed. The results of the questionnaire survey referred to the role and scope of the use of TMS (Transport Management Systems) in road transport companies. As follows from the research presented, the most frequently used applications are not ones based on telematics but rather those belonging to applications related to the creation and management of orders as well as invoicing and payment management.

\begin{tabular}{ll}
\hline Research issues & Author/Authors \\
\hline $\begin{array}{l}\text { ITS - Intelligent Transport Systems } \\
\text { (application of integrated telematics }\end{array}$ & Sowman et al. (2018) \\
systems related to infrastructure & Siergiejczyk et al. (2017) \\
management, exhaust emissions and & Novikov et al. (2017) \\
analysis of ITS applications) & Santa et al. (2016) \\
\hline & Kamenchenko and Grakovski (2015) \\
Safety, tolls, problems related to con- & Omar (2017) \\
gestion on motorways and in urban & Michayevich et al. (2018) \\
agglomerations, control of vehicle & Moriarty and Honnery (2013) \\
flows & Perzyński and Lewiński (2018) \\
& Mishra et al. (2018) \\
\hline $\begin{array}{l}\text { Vehicle navigation systems, technical } \\
\text { and telematics equipment, vehicle on- }\end{array}$ & Ballarin and Zeilinger (2017) \\
-board devices, autonomous vehicles, & Szigeti et al. (2017) \\
other areas related to telematics. & Grakovski and Pilipovecs (2016) \\
& Di Fazio et al. (2016) \\
\hline
\end{tabular}

Table 1. Recent publications describing telematics in road transport Own compilation.

The review of articles on applications of telematics systems in transport presented in Table 1 confirms the set thesis about the lack of research describing the level of application of these solutions in the management of road transport companies which play an extremely important role in supply chains. As follows from the division of issues, the article review concerns a very wide sphere of telematics applications in such areas as intelligent transport systems, road safety support, application of the systems of automatic toll collection, and, finally, systems supporting vehicle control in real time and autonomous vehicles. 
TELEMATICS

SYSTEMS IN ROAD

TRANSPORT

Wojciech Zalewski

\section{Application of telematics systems in road transport in the light of surveys}

In order to empirically verify the proposed research hypothesis and achieve the research objective, a survey was conducted. The survey was conducted by an external research company using the CATI method [3]. Implementation of the study was divided into a few stages which comprise:

- preparation of a questionnaire and conducting pilot studies to confirm whether the content included in the questions would be clear to respondents and whether completing the survey is not too time-consuming, which often results in the lack of reliability of the answers received,

- an initial check that includes a qualitative assessment of the completeness of the answers to the questions asked and rejection of incomplete questionnaires,

- the process of data editing, identification and correction of errors, including spelling mistakes, preparation of tables showing results, compilations, and charts,

- formulating conclusions verifying or denying the research hypotheses set.

The introduction to the survey consisted in conducting a pilot study on a group of 20 randomly selected road transport companies. The main objective of the pilot study was to check the correctness of the questionnaire. The pilot study showed that the questions in the questionnaire are understandable for the surveyed and do not contain any difficult wording, and the time limit set to answer the questions did not exceed 25 minutes. Out of 20 companies in which the author carried out the survey in person, only one company being in possession of three means of transport and operating in international road transport stated that the issue related to telematics systems is completely irrelevant to it.

Due to the pilot study, it was confirmed that the questionnaire was developed correctly and can be directed to the target group of respondents without any changes.

In order to obtain correct and complete results of surveys, it is extremely important to define the population to be examined. Using the so-called permanent features [4] the entities examined were defined in terms of type (i.e. companies operating in road transport), and territory (i.e. companies whose economic activity is registered in the country).

The survey was conducted on a sample of companies belonging to the Association of International Road Transport Carriers in Poland (ZMPD Zrzeszenie Międzynarodowych Przewoźników Drogowych w Polsce) and with the use of information originating from databases of regional road transport associations. ZMPD is the only Polish organization that is a member of the International Road Transport Union (IRU) [5]. The members of this organization are only those companies that provide international and domestic road transport 
services. About 3,800 [6] carriers belong to the ZMPD association, which gives grounds for stating that the selected entities adequately represent the general population.

As some of the companies that are members of ZMPD also provide transport for their own needs, these companies were rejected in the sample population. As a result, by combining the databases, the overall sample from which the companies were drawn was 4,500 enterprises [7]. The study assumed that 500 companies will be drawn from a representative sample of 4,500 transport companies. The draw was based on a systematic random draw. It was also assumed that during the examination in the case of the lack of communication with the surveyed company, there will be another draw so that the final survey could be conducted in 500 business entities. In the draw methodology, stratification in a layered system was abandoned due to the very large fragmentation of road transport in Poland. According to the BOTM data for 2018 [8], only 158 road transport companies in Poland possess more than 100 transport vehicles.

\begin{tabular}{lc}
\hline Status & Number \\
\hline Total population for drawing & 4,500 \\
\hline The sample drawn & 500 \\
\hline $\begin{array}{l}\text { Interviews drawn from the original sample but not made (refusals or } \\
\text { unanswered calls) }\end{array}$ & 48 \\
\hline $\begin{array}{l}\text { Respondents drawn randomly from the remaining population, i.e. from the } \\
\text { group of 4,000 entities }\end{array}$ & 91 \\
\hline \begin{tabular}{l} 
Interviews made \\
\hline Average interview time
\end{tabular} & 500 \\
\hline
\end{tabular}

As already mentioned, 500 survey respondents were drawn, which was dictated by the assumption of obtaining an estimation error of no more than $5 \%$. The selection of the population and the indication of the organization of ZMPD and local associations was also due to the fact that there are many associated companies are among the leading Polish road transport companies both in terms of expertise related to the occupation of road transport operator and economic results achieved. To a large extent, this also results from the involvement of these organizations in the process of organizing training and education for their members.

Among the companies that responded to the survey, $40.4 \%$ conducted business in the form of an entry into business activity register, $36.2 \%$ in the form of a limited liability company, $2.8 \%$ in the form of a joint-stock company, other forms of business activity amounted to $20.6 \%$. As far as the experience in the industry is concerned, $60.6 \%$ of companies had been running business activity for
Table 2. Technical data obtained from the study conducted Own compilation. 
TELEMATICS

SYSTEMS IN ROAD

TRANSPORT

Wojciech Zalewski over 10 years, $22.8 \%$ for more than 5 years and $12.4 \%$ for more than 3 years. Only $3.8 \%$ of the companies examined had more than 100 transport units, $6 \%$ from 50 to $100,15.8 \%$ from 20 to $49,25 \%$ from 10 to 19 , and as much as $49.4 \%$ from 1 to 9 , which confirms the fact of considerable fragmentation of road transport companies in Poland. Regarding the level of employment, 63.8\% of companies employed up to 49 employees, $31.2 \%$ - from 50 to 249 and $5 \%$ of those surveyed employed over 250 employees. $49.2 \%$ of companies conducted a completely homogeneous activity in which $100 \%$ of revenues were obtained from transport activities, $50.6 \%$ of entities conducted operations based on additional sources of income.

In the case of the sample selected in this way, the maximum (admissible) error of estimate $d$ can be estimated by using the formula for the minimum sample size for the estimation of the structure index (see Rószkiewicz, 2002):

$$
n=\frac{z_{\alpha}^{2}}{4 d^{2}}
$$

where:

$z_{\alpha}^{2}$ is the value of distribution function of standardized normal distribution $N(0-1)$ at the significance level of $\alpha=0,05$, and $n$ is the minimum sample size, for the study $\mathrm{n}=108$, while $\mathrm{z} \alpha=1.96$.

In the study conducted, the maximum error of estimation was

$$
d=\sqrt{\frac{z_{0,95}^{2}}{4 \cdot 500}}=\sqrt{\frac{1,96^{2}}{4 \cdot 500}}=0.034,
$$

with the confidence level of $1-\alpha=0.95$ [10]. The admissible error of estimate $d$ is 0.034 , that is $3.34 \%$, and is less than $5 \%$, so that, with high probability, the results of the study can be generalized to a general population including a significant part of companies engaged in road transport.

The key element in the assessment of the level of application of telematics solutions and the level of support in management processes was the analysis of data resulting from the answers to the questions about the scope of the use of their telematics systems, which would also allow verifying the hypothesis set. The second significant measurement was the determination of the independence of features relative to the number of vehicles (the size of the company), the type of business activity, or the scope of transport orders serviced.

Table 3 presents the results from the questionnaires referring to the level and scope of the use of telematics solutions by the surveyed entities. According to the analysis of data, determining the status of the vehicle (z1) is the most important for entrepreneurs. $95 \%$ of respondents answered positively to this scope of the application of telematics solutions. The second important scope is the ability to determine the current location of the vehicle on the map $-87 \%$ of 


\begin{tabular}{|c|c|c|}
\hline $\begin{array}{l}\text { Variable } \\
\text { (z) }\end{array}$ & The scope of application of telematics solutions & $\begin{array}{l}\text { Share of } \\
\text { companies } \\
(\%)\end{array}$ \\
\hline $\mathrm{z} 1$ & Determining the status of a vehicle: on the move or on a stop & 95.00 \\
\hline $\mathrm{z} 2$ & Determining the current location of the vehicle on the map & 87.00 \\
\hline $\mathrm{z} 3$ & $\begin{array}{l}\text { Verification of the correlation of the vehicle's position with the exe- } \\
\text { cution of the order's route }\end{array}$ & 38.60 \\
\hline $\mathrm{z} 4$ & $\begin{array}{l}\text { Determination of the use of drivers' working time in a given 24-hour } \\
\text { driving period }\end{array}$ & 41.60 \\
\hline $\mathrm{z} 5$ & $\begin{array}{l}\text { Analysing whether the driver will be able to arrive at the destination } \\
\text { for the determined time slot for loading or unloading }\end{array}$ & 42.20 \\
\hline $\mathrm{z} 6$ & $\begin{array}{l}\text { Analysing the use of driver's time in the context of the number of } \\
\text { kilometres driven in a given 24-hour period }\end{array}$ & 31.40 \\
\hline $\mathrm{z} 7$ & Analysing driving times and stops & 45.00 \\
\hline z8 & Analysing weekly and bi-weekly time & 26.40 \\
\hline z9 & Analysing the quality of driving style (eco-driving) & 28.00 \\
\hline $\mathrm{z} 10$ & Analysing fuel consumption & 57.80 \\
\hline $\mathrm{z} 11$ & $\begin{array}{l}\text { Determining the punctuality of reaching the destination and unlo- } \\
\text { adings in the supply chain }\end{array}$ & 40.60 \\
\hline $\mathrm{z} 12$ & Reporting delays to customers & 37.60 \\
\hline $\mathrm{z} 13$ & Receiving alerts when the designated route is changed & 30.80 \\
\hline $\mathrm{z} 14$ & Remote transmission of information to the driver via a messenger & 25.80 \\
\hline z15 & $\begin{array}{l}\text { Analysing the legitimacy of refuelling in terms of its quantity and } \\
\text { location of the station }\end{array}$ & 20.20 \\
\hline $\mathrm{z} 16$ & $\begin{array}{l}\text { Remote transfer of documents and order fulfilment confirmation } \\
\text { (CMR) }\end{array}$ & 17.20 \\
\hline $\mathrm{z} 17$ & $\begin{array}{l}\text { Compatibility of telematics systems with cargo exchanges and custo- } \\
\text { mer applications }\end{array}$ & 18.00 \\
\hline z18 & Compatibility with other on-board devices, e.g. refrigeration units & 10.80 \\
\hline z19 & $\begin{array}{l}\text { The possibility of remote interference involving the immobilization } \\
\text { of the vehicle }\end{array}$ & 20.20 \\
\hline $\mathrm{z} 20$ & Connection to alarm systems & 30.20 \\
\hline $\mathrm{z} 21$ & Correlation of a van or truck with a trailer or semi-trailer & 11.60 \\
\hline
\end{tabular}

TELEMATICS SYSTEMS IN ROAD TRANSPORT

Wojciech Zalewski
Table 3. The scope of application of telematics solutions in road transport

Own research. z1 z21 - designation of variables (significant quality features).

respondents. The third one is determining the level of fuel consumption by the telematics system $-57 \%$ of indications. The remaining scopes are significant for only $43 \%$ of respondents and in many cases below 30\%. Also, it can be noticed that the key telematics application scopes for supply chains such as determining the punctuality of reaching the destination and unloadings in the 
TELEMATICS SYSTEMS IN ROAD TRANSPORT

Wojciech Zalewski supply chain (z11-40.6\%), reporting delays to customers (z12-37.6\%) and finally verification of the correlation of the vehicle's position with the execution of the order's route $(\mathrm{z} 3-38.6 \%)$ are valid for a maximum of $43 \%$ of respondents. Other important aspects for the operational activities of road transport companies are remote transfer of documents and order fulfilment confirmation (z16) - only $17.2 \%$, compatibility of telematics systems with cargo exchanges and customer applications (z17) $-18 \%$, or remote transmission of information to the driver via a messenger $(\mathrm{z} 14)-25.8 \%$.

Taking into account all possible scopes suggested in the study and possible to be used by entrepreneurs, it should be pointed out that only 3 of them, i.e. $\mathrm{z} 1$, z2 and z10, obtained a result of above $50 \%$ of affirmative answers. This state of affairs allows for unambiguous confirmation of both the first part of the research hypothesis about the low level of use of telematics solutions as well as the still low quality of services provided. The second part of the hypothesis can be verified positively due to the fact that the key to the implementation of transport orders (tasks) and thus for the quality of services provided were the answers related to $\mathrm{z} 3$, z11 and z12, which were valid for a maximum of $40.6 \%$ of respondents. The results presented in Table 3 and the large random sample allow to make generalizations about the entire population of companies providing road transport services.

The second important element of the study was the demonstration of interdependencies between the applied scope of telematics solutions and such variables as the size of the company, the legal form of business activity, or the territorial scope of the services provided.

In order to examine the interdependencies between selected features of the analysed companies, the chi-square independence test was used [11] due to the fact that the examined features are of qualitative character. Formally, the hypotheses in this test have the following form:

$H_{0}$ the characteristics $\mathrm{X}$ and $\mathrm{Y}$ are independent,

$H_{1}$ the characteristics $\mathrm{X}$ and $\mathrm{Y}$ are dependent.

In order to verify the presented hypotheses about the stochastic independence of variables, the following statistics are used:

$$
\chi^{2}=\sum_{i=1}^{k} \sum_{j=1}^{l} \frac{\left(n_{i j}-\hat{n}_{i j}\right)^{2}}{\hat{n}_{i j}} \sim \chi_{\alpha s}^{2},
$$

where $n_{i j}$ - empirical numbers from the contingency table, $\hat{n}_{i j}$ - theoretical numbers determined according to the formula $\hat{n}_{i j}=\frac{n_{i} \cdot n_{j}}{n}$. The test statistic coincides asymptotically to the distribution $\chi_{\alpha s}^{2}$ with $(s=k-1)(l-1)$ degrees of freedom at a given significance level $\alpha$. The critical area for the chi-square test is right-handed (see Rószkiewicz, 2002). To examine the strength of interdependence of the features for which $\mathrm{H}_{0}$ was rejected for their independence, one can estimate 


\begin{tabular}{|c|c|c|c|c|c|c|c|}
\hline 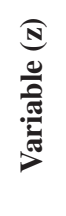 & $\begin{array}{l}\text { The scope of use of } \\
\text { telematics systems }\end{array}$ & 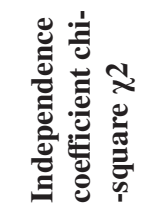 & 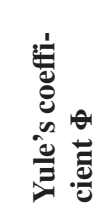 & 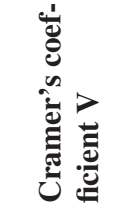 & 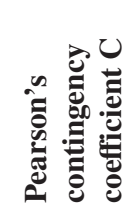 & $\mathbf{p}$ & $\begin{array}{l}\text { Statistical } \\
\text { dependence }\end{array}$ \\
\hline $\mathrm{z} 1$ & $\begin{array}{l}\text { Determining the status } \\
\text { of a vehicle: on the } \\
\text { move or on a stop }\end{array}$ & 15.050 & 0.174 & 0.174 & 0.172 & 0.005 & $\begin{array}{l}\text { significant / } \\
\text { weak }\end{array}$ \\
\hline $\mathrm{z} 2$ & $\begin{array}{l}\text { Determining the } \\
\text { current location of the } \\
\text { vehicle on the map }\end{array}$ & 5.195 & 0.102 & 0.102 & 0.102 & 0.268 & insignificant \\
\hline $\mathrm{z} 3$ & $\begin{array}{l}\text { Verification of the } \\
\text { correlation of the } \\
\text { vehicle's position with } \\
\text { the execution of the } \\
\text { order's route }\end{array}$ & 67.286 & 0.368 & 0.368 & 0.346 & 0.000 & $\begin{array}{l}\text { significant / } \\
\text { moderate }\end{array}$ \\
\hline z4 & $\begin{array}{l}\text { Determining the use } \\
\text { of drivers' working } \\
\text { time a given 24-hour } \\
\text { driving period }\end{array}$ & 82.159 & 0.457 & 0.457 & 0.377 & 0.000 & $\begin{array}{l}\text { significant / } \\
\text { strong }\end{array}$ \\
\hline $\mathrm{z} 5$ & $\begin{array}{l}\text { Analysing whether the } \\
\text { driver will be able to } \\
\text { arrive at the destina- } \\
\text { tion for the determined } \\
\text { time slot for loading or } \\
\text { unloading }\end{array}$ & 56.236 & 0.337 & 0.337 & 0.319 & 0.000 & $\begin{array}{l}\text { significant / } \\
\text { moderate }\end{array}$ \\
\hline z6 & $\begin{array}{l}\text { Analysing the use of } \\
\text { driver's time in the } \\
\text { context of the number } \\
\text { of kilometres driven in } \\
\text { a given 24-hour period }\end{array}$ & 78.491 & 0.398 & 0.398 & 0.370 & 0.000 & $\begin{array}{l}\text { significant / } \\
\text { moderate }\end{array}$ \\
\hline $\mathrm{z} 7$ & $\begin{array}{l}\text { Analysing driving } \\
\text { times and stops }\end{array}$ & 57.635 & 0.341 & 0.341 & 0.323 & 0.000 & $\begin{array}{l}\text { significant / } \\
\text { moderate }\end{array}$ \\
\hline z8 & $\begin{array}{l}\text { Analysing weekly and } \\
\text { bi-weekly time }\end{array}$ & 60.013 & 0.348 & 0.348 & 0.329 & 0.000 & $\begin{array}{l}\text { significant / } \\
\text { moderate }\end{array}$ \\
\hline z9 & $\begin{array}{l}\text { Analysing the quality } \\
\text { of driving style (eco- } \\
\text {-driving) }\end{array}$ & 56.056 & 0.336 & 0.336 & 0.319 & 0.000 & $\begin{array}{l}\text { significant / } \\
\text { moderate }\end{array}$ \\
\hline z10 & $\begin{array}{l}\text { Analysing fuel con- } \\
\text { sumption }\end{array}$ & 18.505 & 0.193 & 0.193 & 0.190 & 0.001 & $\begin{array}{l}\text { significant / } \\
\text { weak }\end{array}$ \\
\hline z11 & $\begin{array}{l}\text { Determining the punc- } \\
\text { tuality of reaching the } \\
\text { destination and unlo- } \\
\text { adings in the supply } \\
\text { chain }\end{array}$ & 62.607 & 0.335 & 0.335 & 0.335 & 0.000 & $\begin{array}{l}\text { significant / } \\
\text { moderate }\end{array}$ \\
\hline
\end{tabular}

TELEMATICS SYSTEMS IN ROAD TRANSPORT

Wojciech Zalewski 
TELEMATICS

SYSTEMS IN ROAD

TRANSPORT

Wojciech Zalewski

Table 4. continued

\begin{tabular}{|c|c|c|c|c|c|c|c|}
\hline 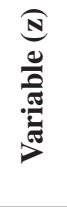 & $\begin{array}{l}\text { The scope of use of } \\
\text { telematics systems }\end{array}$ & 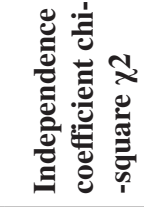 & 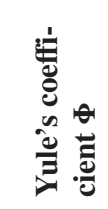 & 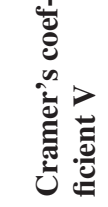 & 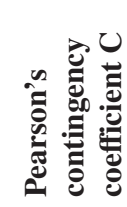 & $\mathbf{p}$ & $\begin{array}{l}\text { Statistical } \\
\text { dependence }\end{array}$ \\
\hline z12 & $\begin{array}{l}\text { Reporting delays to } \\
\text { customers }\end{array}$ & 73.933 & 0.386 & 0.386 & 0.360 & 0.000 & $\begin{array}{l}\text { significant / } \\
\text { moderate }\end{array}$ \\
\hline z13 & $\begin{array}{l}\text { Receiving alerts when } \\
\text { the designated route is } \\
\text { changed }\end{array}$ & 83.452 & 0.460 & 0.460 & 0.378 & 0.000 & $\begin{array}{l}\text { significant / } \\
\text { strong }\end{array}$ \\
\hline z14 & $\begin{array}{l}\text { Remote transmission } \\
\text { of information to the } \\
\text { driver via a messenger }\end{array}$ & 72.264 & 0.382 & 0.382 & 0.357 & 0.000 & $\begin{array}{l}\text { significant / } \\
\text { moderate }\end{array}$ \\
\hline z15 & $\begin{array}{l}\text { Analysing the legiti- } \\
\text { macy of refuelling in } \\
\text { terms of its quantity } \\
\text { and location of the } \\
\text { station }\end{array}$ & 42.403 & 0.292 & 0.292 & 0.281 & 0.000 & $\begin{array}{l}\text { significant / } \\
\text { moderate }\end{array}$ \\
\hline z16 & $\begin{array}{l}\text { Remote transfer of } \\
\text { documents and order } \\
\text { fulfilment confirma- } \\
\text { tion (CMR) }\end{array}$ & 107.673 & 0.488 & 0.488 & 0.422 & 0.000 & $\begin{array}{l}\text { significant / } \\
\text { strong }\end{array}$ \\
\hline z17 & $\begin{array}{l}\text { Compatibility of tele- } \\
\text { matics systems with } \\
\text { cargo exchanges and } \\
\text { customer applications }\end{array}$ & 61.299 & 0.352 & 0.352 & 0.332 & 0.000 & $\begin{array}{l}\text { significant / } \\
\text { moderate }\end{array}$ \\
\hline z18 & $\begin{array}{l}\text { Compatibility with } \\
\text { other on-board devi- } \\
\text { ces, e.g. refrigeration } \\
\text { units }\end{array}$ & 56.858 & 0.339 & 0.339 & 0.321 & 0.000 & $\begin{array}{l}\text { significant / } \\
\text { moderate }\end{array}$ \\
\hline z19 & $\begin{array}{l}\text { The possibility of } \\
\text { remote interference } \\
\text { involving the immobi- } \\
\text { lization of the vehicle }\end{array}$ & 64.495 & 0.361 & 0.361 & 0.339 & 0.000 & $\begin{array}{l}\text { significant / } \\
\text { moderate }\end{array}$ \\
\hline z20 & $\begin{array}{l}\text { Connection to alarm } \\
\text { systems }\end{array}$ & 61.189 & 0.351 & 0.351 & 0.331 & 0.000 & $\begin{array}{l}\text { significant / } \\
\text { moderate }\end{array}$ \\
\hline z21 & $\begin{array}{l}\text { Correlation of a van or } \\
\text { truck with a trailer or } \\
\text { semi-trailer }\end{array}$ & 45.868 & 0.304 & 0.304 & 0.291 & 0.000 & $\begin{array}{l}\text { significant } \\
\text { moderate }\end{array}$ \\
\hline
\end{tabular}


the strength of the relationship based on statistics $\chi^{2}$. These are (see Sobczyk, 2000):

a) Yule's coefficient $\phi=\sqrt{\frac{\chi^{2}}{n}}$,

b) Cramer's coefficient $V=\sqrt{\frac{\phi^{2}}{\min (k-1, l-1)}}$,

c) Pearson's contingency coefficient $C=\sqrt{\frac{\phi^{2}}{1+\phi^{2}}}$.

All these coefficients take values from 0 to 1 , where zero means the independence of the variables tested. The higher the coefficients, the greater the interdependence of the characteristics studied. It is assumed that if the coefficient is less than 0.2 , the dependence strength is weak, from 0.2 to 0.4 - moderate, and above 0.45 - significant/strong.

Table 4 presents the summary results of chi-square independence test for 21 significant scopes of application of telematics solutions depending on the size of the transport company, i.e. the number of transport units possessed. Notably, only for two scopes, i.e. determining the use of drivers' working time a given 24-hour driving period $(\mathrm{z} 4)$ and receiving alerts when the designated route is changed (z13), the statistical dependence is strong. In other cases, it is moderate or weak for the proposed scale and in one case it is statistically insignificant. This allows concluding that in large organizations there is a need for a very thorough analysis of both the use of drivers' working time (dependence on the number of kilometres driven) and a very detailed analysis of routes on which the drivers perform orders due to the control of current travel costs. In other cases the level of dependence is small.

A similar analysis of chi-square independence [12] was carried out in relation to the indicated scopes, in relation to the form of business activity as well as the scope of services provided. In the case of the form of business activity, 6 scopes are statistically insignificant for the respondents, which means rejection of the null hypothesis, and for the majority of scopes they are weak and moderate. Thus, the form of activity does not have a significant impact on the level of application of telematics solutions.

In the case of the scopes of services performed, the survey indicated a strong statistical dependence in relation to determining the punctuality of reaching the destination and unloadings (z11), i.e. punctuality of services in the supply chain. This relationship indicates that the greater the territorial scope of the services provided (international transport) by entrepreneurs, the more important for them is the quality of orders and thus the use of telematics solutions. In the remaining 
TELEMATICS

SYSTEMS IN ROAD

TRANSPORT

Wojciech Zalewski
13 scopes, there is moderate dependence and in 7 cases weak depending on the scope of transport services provided.

\section{Summary}

The universality of applying telematics solutions in various areas of economic life is considerable, as indicated in literature studies as well as by the research conducted on the advancement of telematics solutions in relation to road transport companies. Over $92 \%$ of respondents have telematics devices installed in their vehicles that support transport management. Unfortunately, the scope of using functions that these solutions possess is still very small. The survey on a sample of 500 entities showed clearly that for companies it is still not very important to analyse the quality of orders (their punctuality) and more important is the analysis of the driver's working time (abuses are associated with severe penalties) and control of the route of the vehicle which may involve excessive costs and a low margin on commission.

The questionnaire study presented clearly allowed to verify the proposed hypothesis according to which the low level of use of telematics solutions by road transport companies in Poland reduces the efficiency of integrated supply chains, since it reduces the quality of services. In addition, a comprehensive analysis of both the literature research on the subject and the research carried out allows for drawing the following conclusions:

- despite the fact that telematics systems are commonly used by road transport companies, their scope of use is still very low, which may be related to the still low level of awareness of managers or to little interest from companies ordering transport (e.g. producers, trading companies, etc.) to receive reliable information, often without human participation, on the quality of services provided;

- the low use of telematics solutions may be related to the need for additional employment of a person analysing and reporting individual scopes of using the systems;

- an important element in the quality of services provided by road transport companies in the supply chain may be the lack of standardization of telematics solutions used and the format of data transmission.

\section{Notes}

[1] The research was financed by the Scientific Grant Miniature 2 of the National Science Centre, Poland, no. 2018/02/X/HS4/00107, entitled 'Support for logistic processes in road transport using telematics systems'

[2] The Consultative Committee for International Telegraphy \& Telephony is an international advisory committee for the standardization of telecommunications networks; currently replaced by the International Telecommunications Union (ITU). 
[3] CATI (computer-assisted telephone interviewing) is a method of gathering information in quantitative market and public opinion research.

[4] Permanent features are described in Walczak T. (1999), Zasady projektowania i realizacji badań statystycznych, Central Statistical Office (GUS), Warsaw.

[5] IRU - International Road Union - organization based in Geneva, associating over 157 national road transport organizations.

[6] In June 2019, the number of ZMPD members was approximately 3,900 enterprises. Information obtained from the ZMPD services section from 04.06.2019.

[7] Finally, 3,750 companies were derived from the ZMPD database and 750 from the provincial associations' databases.

[8] BOTM is the abbreviation of Biuro Obstugi Międzynarodowego Transportu Drogowego (the International Road Transport Service Department of the Ministry of Infrastructure).

[9] The survey was commissioned to the Instytut Badawczy IPC Sp. z o.o.

[10] The confidence level is a predetermined probability with which an unknown parameter will be in the estimated confidence interval. 95\% confidence level is the standard value adopted in statistical surveys. More can be found, for example, in Jóźwiak J. Podgórski J. (2009), Statystyka od podstaw, PWE, Warsaw.

[11] More about the chi-square independence test can be found in the works of Greenwood P.E., Nikulin M.S. (1996) A guide to chi-squared testing, Wiley, New York; Corder G.W., Foreman D.I. (2009). Nonparametric Statistics for Non-Statisticians: A Step-by-Step Approach Wiley, Agresti A. (2002), Categorical Data Analysis, Second Edition, John Wiley \& Sons, New York.

[12] Detailed tables of contingency for the examined features for the indicated cases are available from the author of the study.

\section{References}

Ballarin, C., Zeilinger, M., "The Truck of the Future: Autonomous and Connected Driving at Daimler Trucks", SAE Technical Paper 2017-01-1931, 2017. DOI: 10.4271/2017-01-1931

Bujak A., Orzeł A., Miler R. (2014), ,Telematics of Supplay Chainn - Areas Opportunites, Challenges", in: Mikulski J. (Ed.), Communications in Computer and Information Science, Vol. 471, pp. 185-195.

Cattaruzza, D., Absi, N., Feillet, D., Gonzales-Feliu, J. (2017), "Vehicle routing problems for city Logistics", EURO Journal on Transportation and Logistics, Vol. 6 No. 1, pp. 51-79.

Di Fazio, A., Bettinelli, D., Louette, E. (2016), "European pathways to introduce EGNOS and Galileo for dangerous goods transport", Transport Research Arena, Book Series: Transportation Research Procedia, Vol. 14, pp. 1482-1491.

Farmer, C.M., Kirley, B.B, McCart, A.T. (2000), "Effects of in- vehicle monitoring on the driving behawior of teenagers", Journal of Safety Research, Vol. 41 No. 1, pp. 39-45.

Filipowicz, J. (2005), „Nowoczesny system monitoringu pracy kierowców i zarządzania flotą pojazdów”, II Konferencja Naukowo-Techniczna LOGITRANS nt. „Logistyka, Systemy Transportowe, Bezpieczeństwo w Transporcie”, Szczyrk, 12-14 kwietnia
TELEMATICS

SYSTEMS IN ROAD

TRANSPORT

Wojciech Zalewski 
TELEMATICS SYSTEMS IN ROAD TRANSPORT

Wojciech Zalewsk
2005, Politechnika Radomska, Prace Naukowe „Transport” nr 1/21, sekcja „Budowa i eksploatacja środków transportu".

Filipowicz, J., Hober, W. (2007), „Nowoczesne programy wspomagania analizy pracy układu „kierowca”pojazd”, IV Konferencja Naukowo-Techniczna LOGITRANS nt. „Logistyka, Systemy Transportowe, Bezpieczeństwo w Transporcie”, Szczyrk, 25-27 kwietnia 2007.

Grakovski, A., Pilipovecs, A. (2017), "Multi-Purpose Fibre Optic System for Automated Vehicle's Weighting-in-Motion and Classification in Applications of Intelligent Transport Systems", IEEE International Conference on Models and Technolod gies for Intelligent Transportation Systems (MT-ITS), $20175^{\text {th }}$ IEEE International Conference on Models and Technologies for Intelligent Transportation Systems (mtits), pp. 610-615.

Grakovski, A., Pilipovecs, A. (2016), "Dynamics of Interaction between the Road Suri face and Vehicle's Wheel in Fibre-Optic System for Automatic Weighing in Motion of Transport", Proceedings of the $16^{\text {th }}$ International Scientific Conference Reliability and Statistics in Transportation and Communication (relstat-2016), Book Series: Procedia Engineering, Vol. 178, pp. 5-12.

Harris, L., Wang, Y., Wang, H. (2015), "ICT in multimodal transport and technological trends: Unleashing potencial for future", International Journal of Production Economics, Vol. 159, pp. 88-103.

IEEE Vehicular Networking Conference (VNC), Columbus, Book Series: IEEE Vehicular Networking Conference, ISSN: 2157-9865.

Kamenchenko, S., Grakovski, A. (2015), "Increased Safety of Data Transmission for "Smart" Applications in the Intelligent Transport Systems", $10^{\text {th }}$ International Conference on Dependability and Complex Systems (DepCoS-RELCOMEX), Brunow, Theory and engineering of complex systems and dependability, Book Series: Advances in Intelligent Systems and Computing, Vol. 365, pp. 185-194.

Khalil Omar, K. (2017), "A Study on Road Accidents in Abu Dhabi Implementing a VehiĐ cle Telematics System to Reduce Cost, Risk and Improve Safety", $10^{\text {th }}$ International Conference on Developments in eSystems Engineering (DeSE), Paris, Book Series: International Conference on Developments in eSystems Engineering, pp. 195-200.

Kiba-Janiak, M., Tronina, P. (2017), „Wpływ systemów telematycznych na usprawnienie międzynarodowych łańcuchów dostaw”, Zeszyty Naukowe Politechniki Śląskiej. Seria Organizacja i zarzadzanie, No. 103, pp. 79-93.

Lacny, J. (2010), Funkcjonowanie międzynarodowego transportu drogowego ładunków w gospodarce globalnej, Wydawnictwo WSG, Bydgoszcz.

Michałowska, M., Ogloziński, M. (2016), “The Impact of the Tolling System for Road Traffic Safety", $16^{\text {th }}$ International Conference on Transport Systems Telematics (TST), Katowice Ustron, Book Series: Communications in Computer and Information Science, Vol. 640, pp. 235-242.

Mikulski, J. (2007), „Obecny stan w dziedzinie telematyki systemów transportowych”, Czasopismo Technika Transportu Szynowego, Vol. 13 No. 11, pp. 51-55.

Mikulski, J., Nowak, I. (2010), „Telematyka -przyszłość transportu i logistyki?”, Logistyka, No. 2. 
Minni, R. (2013), “A cost Efficient Real Time Vehicle Tracking System”, International Journal of Computer Applications, Vol. 81 No. 11, pp. 29-35.

Mishra, S., Bhattacharya, D., Gupta, A. (2018), "Congestion Adaptive Traffic Light Control and Notification Architecture Using Google Maps APIs", Open Access Journals, Vol. 3 No. 4.

Moriarty, P., Honnery, D. (2013), "Safety impacts of vehicular information technology", International Journal Vehicle Design, Vol. 31 No. 2, pp. 176-186.

Nikolayevich, B.V., Kudryavcev, A., Duque-Sarango, M., Jose, M. (2018), “Analysis of the implementation of telematic tools for data management of passenger traffic dynamics in the Bus Rapid Transit system", Revista Facultad de Ingenieria, Vol. 27 No. 49, pp. 49-56.

Novikov, A., Pribyl, P., Vasileva, V., et al. (2017), "ITS Control of Highways Capacity", in: $12^{\text {th }}$ International Conference on Road Organization and Safety in Big Cities, St. Petersburg, Book Series, Transportation Research Procedia, Vol. 20, pp. 468-473.

Nowacki, G. (Ed.) (2006), Telematyka transportu drogowego, Wydawnictwo ITS Warszawa.

Perzyński, T., Lewiński, A. (2018), “The influence of new telematics solutions on the improvement the driving safety in road transport", Management Perspective for Transport Telematics, Springer, pp. 101-114.

Riha, Z., Tichy, J. (2015), ,The Costs Calculation and Modeling in Transport in Transport Means", Kaunas, pp. 388-391.

Rószkiewicz, M. (2002), Metody ilościowe w badaniach marketingowych, PWN, Warszawa.

Santa, J., Fernandez, P.J., Zamora, M.A. (2016), “Cooperative ITS for Two-Wheel Vehicles to Improve Safety on Roads", in: 2016 IEEE Vehicular Networking Conference (VNC), December 2016, pp. 254-257.

Schuessler, N., Axhausen, K., (2009), "Processing raw data from global positioning systems without additional information. Transportation Research Record", Journal of the Transportation Research Board, Vol. 2105 No. 1, pp. 28-36.

Siergiejczyk, M., Krzykowska, K., Rosinski, A., Grieco, L.A. (2017), "Reliability and viewpoints of selected ITS system", in: 25 International Conference on Systems Engineering, University Nevada, IEEE, pp. 141-146.

Sobczyk, M. (2000), Statystyka: Podstawy teoretyczne, przykłady - zadania, Wydawnictwo UMSC, Lublin.

Sowman, J., Box, S., Wong, A., Grote, M., Laila, D.S., Gillam, N.G., Cruden, A., Preston, J., Fussey, P. (2018), "In-use emissions testing of diesel-driven buses in Southampton: is selective catalytic reduction as effective as fleet operators think?", IET Intelligent Transport Systems Journal, Vol. 12 No. 6, pp. 521-526.

Szigeti, S., Csiszar, C., Foldes, D. (2017), "Information Management of Demand-Respon 0 sive Mobility Service Based on Autonomous Vehicles", Transportation Science and Technology, Vol. 187, pp. 483-491.

Szymonik, A. (2010), Technologie informatyczne w logistyce, Wydawnictwo Placed, Warszawa.

Wahlstrom, J., Skog, I., Handel, P. (2014), “Detection of Dangerous Cornering in GNSS 
TELEMATICS

SYSTEMS IN ROAD

TRANSPORT

Wojciech Zalewski data driven Insurance Telematics", IEEE Transaction of Intelligent Transport Systems, Vol. 16 No. 6, pp. 3073-3083.

Walker, G., Manson, A. (2014), "Telematics, urban freight logistics and low carbon road networks", Journal of Transport Geography, Vol. 37, pp. 74-81.

Wydro, K.B. (2005), „Telematyka - znaczenie i definicja terminu”, Telekomunikacja i techniki Informacyjne, Vol. 1-2, pp. 116-130.

Yan, X., Wang, J., Wu, J. (2016), "Effect of In-Vehicle Audio Warning System on Driver's Speed Control Performance in Transition Zones from Rural Areas to Urban Areas", International Journal Enviromental Research Public Health, Vol.13 No. 7. 